\title{
A New Technology of Process Water Treatment Using Fluid-Jet Cavitation
}

\author{
Takaharu Noda $^{* 2}$, Hiromichi Tsuji ${ }^{\text {a) }}$ \\ and Shisei Goto \\ NPi Research Laboratory, Nippon Paper Industries Co., Ltd. ${ }^{* 1}$
}

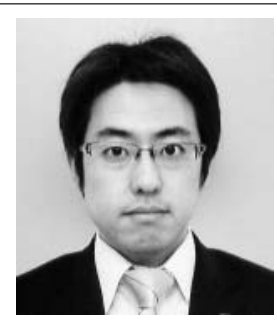

Takaharu Noda

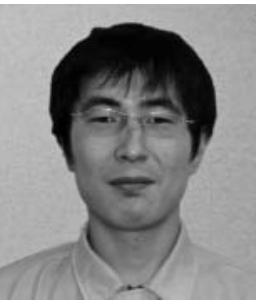

Hiromichi Tsuji

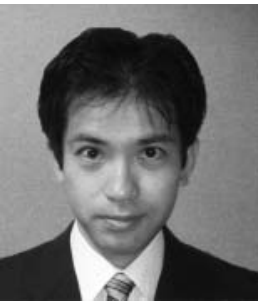

Shisei Goto

\begin{abstract}
A new technology using fluid-jet cavitation (CV-jet) has been developed in order to improve the quality of secondary fibers. CV-jet treatment was applied to process water in deinking. In this treatment, process water was injected into the reacting vessel by using a high-speed jet and cavitation bubbles were generated around the jet. The impact force produced by the collapse of the cavitation bubbles detached contaminants, such as ink and binder, from the surface of fines and ash particles. The effects of $\mathrm{CV}$-jet treatments for process water in deinking were investigated in terms of the number of dirt speckles, the effective residual ink concentration (ERIC) and the brightness of the treated samples.

The results showed that $\mathrm{CV}$-jet treatment decreased the average size of dirt speckles in the process water, and the treatment also facilitated ink detachment from the fines in the water. The number and average size of dirt speckles after $\mathrm{CV}$-jet treatment were decreased by the subsequent flotation. And the degree of dirt reduction after CV-jet treatment was much higher than without the treatment. The brightness of the fines after CVjet treatment was also improved by the subsequent flotation. Similarly, the brightness gain through the flotation after $\mathrm{CV}$-jet treatment was much higher than without the treatment. These results indicated that $\mathrm{CV}$-jet treatments improved the quality of the fines in the process water, which were difficult to be improved by conventional deinking devices. Therefore, the $\mathrm{CV}$-jet technology has the potential to improve deinking process.
\end{abstract}

Keywords : cavitation, process water, dirt speckle, ink detachment, fines

\section{Introduction}

More and more amount of deinked pulp (DIP) is being used these days to save resources and reduce pulp production cost. DIP for printing and writing paper requires high brightness and low dirt speckle level. As demand of

\footnotetext{
${ }^{* 1}$ 15-21-1 Oji, Kita-ku, Tokyo 114-0002, Japan

${ }^{* 2} \mathrm{E}$-mail : takaharu-noda@np-g.com

${ }^{a}$ Current department : Iwanuma Mill, Nippon Paper Industries Co., Ltd.
}

paper labeled as recycled is growing in those markets, quality requested for reclaimed waste paper from which DIP is made, along with quality of resultant DIP itself, is getting severer. On the other hand, printing process is diversifying and unfavorable contaminants for DIP production are in greater use like tonner which is difficult to be removed and ink of special grade using hardening resin such as UV ink. This trend has been degrading quality of reclaimed waste paper year after year.

In DIP plant, process water (white water) is circulated and reused. As process water contains contaminants like 
ink, reusing it without any treatment will deteriorate quality of DIP like brightness and dirt speckle level. Therefore, process water is treated by flotation $(\mathrm{F} / \mathrm{T})$ and then fed back to the process in most cases. As most of contaminants adhere to fiber fines and ash particles suspended in process water $^{1-3)}$, removing them results in discharging fine fraction out of the process which causes low pulp yield in DIP production. Large amount of discharge is also unfriendly to environment. To detach substances attached on fiber surface, equipment like kneader and disperser is commonly used ${ }^{4)}$. They have to be operated at high pulp consistency more than $25 \%$ for good performance. Since solid content of process water is less than $3 \%$ in most cases, they can't release contaminants from fine fraction. In other words, no method is available for removing contaminants like ink from process water at the moment.

We have developed a new deinking and refining process, using fluid-jet cavitations ${ }^{5-7)}$. In our process, fluid-jet cavitations ( $\mathrm{CV}$-jet) produce bubbles. When bubbles collapse, impact force generated detaches ink and brakes dirt speckles. Our CV-jet treatment unit was able to detach tonner and ink without help of deinking chemicals and heating, and could break down them efficiently so that fiber was less damaged during deinking ${ }^{8) 9}$. As CV-jet treatment took off contaminants effectively at a relatively low consistency range (less than $4 \%$ ), treating process water with it was promising. In this paper, we studied its possibility and evaluated the effect on ink and dirt speckles there. Then, process water was followed with flotation, and how pre-treatment by $\mathrm{CV}$-jet affected removal efficiency of contaminants at flotation $(\mathrm{F} / \mathrm{T})$ was investigated.

\section{Experiment}

\section{1 Samples}

Test 1 : Effect on size reduction of dirt speckles and their removal by $\mathrm{F} / \mathrm{T}$ with model process water

Coated paper was printed, shredded and disintegrated in low consistency pulper at $40^{\circ} \mathrm{C}$ for 10 minutes with sodium hydroxide ( $1 \%$ per O. D. pulp) being added. Pulp slurry was squeezed through a Teflon bag of 80 mesh opening. The filtrate was model process water for test 1 . Its solid content was $0.5 \%$.

Test 2 : Effect on ink removal with mill process water

Mill process water was obtained from an intermediate thickener in a DIP plant for newsprint in Mill A. Its solid content was $1.2 \%$.

Test 3 : Effect on removal at $\mathrm{F} / \mathrm{T}$ with mill process water

Mill process water was obtained from washer in a DIP plant for newsprint in Mill B. Its solid content was 1. 7\%.

\section{2. $2 \mathrm{CV}$-jet treatment}

The CV-jet device used in this study was based on the

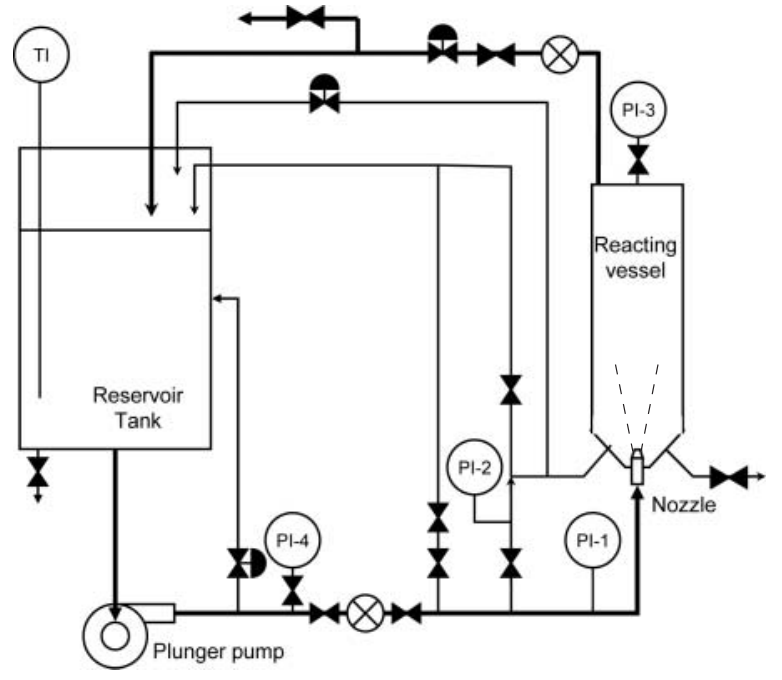

Fig. 1 Mechanism of cavitating jet device.

PI : pressure gage, TI : temperature sensor.

apparatus for washing metal surface ${ }^{10), 11)}$ which was designed to deink and refine pulp fiber. It is shown in Fig. 1. The specification of $\mathrm{CV}$-jet was as follows

Output pressure of plunger pump : $7 \mathrm{Mpa}$

Pressure inside reactor : $0.3 \mathrm{MPa}$

Mode of treatment: Test 1 and $3:$ circulated Test 2 : one-pass only

Time of treatment: Test $1: 15$ minutes Test $3: 10$ minutes

Chemicals : not charged

\subsection{Flotation $(\mathrm{F} / \mathrm{T})$ treatment}

Test 1

$\mathrm{F} / \mathrm{T}$ volume $: 5 \mathrm{~L}$

Time for flotation $: 3$ minutes

Temperature : $15^{\circ} \mathrm{C}$

Air flow rate $: 5 \mathrm{~L} / \mathrm{min}$.

Deinking agent $: 0.2 \%(\mathrm{v} / \mathrm{v}) \quad($ poly-alcoholic type)

Test 3

$\mathrm{F} / \mathrm{T}$ volume $: 2 \mathrm{~L}$

Time for flotation :

Untreated : 2, 3, 4 minutes, respectively

CV treated : 3, 5, 7 minutes, respectively

Temperature : $40^{\circ} \mathrm{C}$

Air flow rate $: 1.3 \mathrm{~L} / \mathrm{min}$.

Deinking agent : not charged

\subsection{Evaluation}

Test 1 :

Samples were taken before and after CV-jet treatment. Then, they were processed with flotation. From every sample, volume equivalent to $2 \mathrm{~g}$ of solid was taken out and filtrate pads were made with Buchner funnel. The number of dirt speckles was measured by dirt analyzer of scanner type (Spec Scan 2000 by Apogee System Inc.).

Test 2 : 
Samples were taken before and after CV-jet treatment. They were hyper-washed on a wire of 325 mesh of which opening was $44 \mu \mathrm{m}$. From every sample, volume equivalent to $2 \mathrm{~g}$ of solid was taken out and filtrate pads were made with Buchner funnel. The pad was evaluated its effective residual ink concentration (ERIC) and ISO brightness. ERIC was determined by Color Touch 2 by Technidyne Co. and ISO brightness by color-difference meter by Murakami Color Research Laboratory Co., Ltd.

\section{Test 3:}

Samples were taken before and after CV-jet treatment. Then, they were processed with flotation. From every sample, volume equivalent to $2 \mathrm{~g}$ of solid was taken out and filtrate pads were made with Buchner funnel. Effective residual ink concentration (ERIC) and ISO brightness were measured.

\section{Result and discussion}

3.1 Effect on size reduction of dirt speckles and their removal by $\mathrm{F} / \mathrm{T}$

(Test 1 : Effect on size reduction of dirt speckles and their removal by $\mathrm{F} / \mathrm{T}$ with model process water)

Model process water was treated by $\mathrm{CV}$-jet for $15 \mathrm{~min}$ utes. Then, model process waters, original and one after treated, were processed with flotation. The result was in Table 1. Reject percentage at $\mathrm{F} / \mathrm{T}$ was $6.3 \%$ in the blank (the original) and $10.5 \%$ in the CV-jet-jet treated. The result before $\mathrm{F} / \mathrm{T}$ treatment was compared with each other. The $\mathrm{CV}$-jet treatment significantly increased the number of dirt speckles larger than 100 microns. In contrast, the treatment reduced the number of dirt speckles over 250 microns. The average speckle diameter was also decreased. These suggested that dirt speckles of which size was larger than 250 microns were broken down to smaller size and the number of dirt speckles of which size was between 100 microns and 250 microns increased. Then, the effect of $\mathrm{F} / \mathrm{T}$ was compared in both cases. F/T treatment reduced number of dirt in the blank as well as in the $\mathrm{CV}$-jet treated. The degree of dirt reduction, however, was far greater in the $\mathrm{CV}$-jet treated than the blank, and the $\mathrm{CV}$-jet treated had less number of dirt speckles.
The reason would be:

1) CV-jet treatment broke down dirt speckles to size which could be more efficiently removed by $\mathrm{F} / \mathrm{T}$.

2) Ink which was colored and adhered to fine fraction in process water was detached and could be more easily removed by $\mathrm{F} / \mathrm{T}$.

Regarding item 2, process water used in test 1 was made from coated paper. As ink was supposed to be attached on ash particles, the $\mathrm{CV}$-jet-jet treatment might detach ink from them.

In a case where DIP was produced from coated paper, the CV-jet treatment broke down dirt speckles and improved the efficiency of dirt removal at $\mathrm{F} / \mathrm{T}$. Thus it was shown that the quality of fine fraction in process water after $\mathrm{F} / \mathrm{T}$ was improved.

3.2 The effect on ink detachment of the CV-jet treatment and ink removal at flotation.

(Test 2: Ink detachment test with mill process water

Test $3:$ Effect on ink removal at $\mathrm{F} / \mathrm{T}$ )

How the CV-jet treatment worked on ink detachment was studied in Test 2, and its result was in Table 2. Before hyper-washing, there was little difference between the blank and the $\mathrm{CV}$-jet treated as far as brightness and ERIC value were concerned. After hyper-washing, the CV -jet treated had higher brightness and lower ERIC value. The fact suggested that ink adhering to fine fraction in process water was detached by the $\mathrm{CV}$-jet treatment and detached ink was removed by following washing. Because mill process water in Test 2 was sampled from DIP plant using newsprint as a resource, ink was supposed to be at-

Table 2 The results of the $\mathrm{CV}$-jet treatment, Exp. \#2. CV: CV-jet treatment. The samples were hyper-washed on a $325^{-}$-mesh wire

\begin{tabular}{l|c|c|c|c}
\hline \multirow{2}{*}{} & \multicolumn{2}{|c|}{ Before hyper-washing } & \multicolumn{2}{c}{ After hyper-washing } \\
\cline { 2 - 5 } & $\begin{array}{c}\text { Brightness } \\
\%\end{array}$ & $\begin{array}{c}\text { ERIC } \\
\text { ppm }\end{array}$ & $\begin{array}{c}\text { Brightness } \\
\%\end{array}$ & $\begin{array}{c}\text { ERIC } \\
\text { ppm }\end{array}$ \\
\hline Blank & 51.0 & 814 & 60.8 & 119 \\
\hline CV & 51.1 & 778 & 62.7 & 66 \\
\hline
\end{tabular}

Table 1 The results of dirt measurement, Exp. \#1.CV: CV-jet treatment for 15 minutes

\begin{tabular}{l|c|c|c|c|c|c}
\hline \multirow{2}{*}{} & \multicolumn{3}{|c|}{ Before flotation } & \multicolumn{3}{c}{ After flotation } \\
\cline { 2 - 6 } & $\begin{array}{c}\text { Number of dirt speckles } \\
\text { counts } / \mathrm{m}^{2}\end{array}$ & $\begin{array}{c}\text { Average speckle } \\
\text { diameter }\end{array}$ & $\begin{array}{c}\text { Number of dirt speckles } \\
\text { counts } / \mathrm{m}^{2}\end{array}$ & $\begin{array}{c}\text { Average } \\
\text { diameter }\end{array}$ \\
\cline { 2 - 3 } & $>\phi 100 \mu \mathrm{m}$ & $>\phi 250 \mu \mathrm{m}$ & $\mu \mathrm{m}$ & $>\phi 100 \mu \mathrm{m}$ & $>\phi 250 \mu \mathrm{m}$ & $\mu \mathrm{m}$ \\
\hline Blank & 260,000 & 97,000 & 238 & 140,000 & 10,000 & 105 \\
\hline $\mathrm{CV}$ & 480,000 & 27,000 & 108 & 27,000 & 200 & 58 \\
\hline
\end{tabular}


Table 3 The results of $\mathrm{CV}$-jet treatment and flotation experiment, Exp. \#3. CV : $\mathrm{CV}^{-}$ et treatment for 10 minutes

\begin{tabular}{lccc}
\hline & $\begin{array}{c}\text { Reject percentage } \\
\%\end{array}$ & $\begin{array}{c}\text { Brightness } \\
\%\end{array}$ & $\begin{array}{c}\text { ERIC } \\
\text { ppm }\end{array}$ \\
\hline Blank & - & 57.9 & 601 \\
& 32.6 & 59.9 & 473 \\
& 44.9 & 61.1 & 393 \\
& 47.8 & 61.3 & 372 \\
\hline CV & - & 57.8 & 615 \\
& 25.9 & 62.0 & 388 \\
& 35.0 & 64.3 & 277 \\
& 44.8 & 65.9 & 192 \\
\hline
\end{tabular}

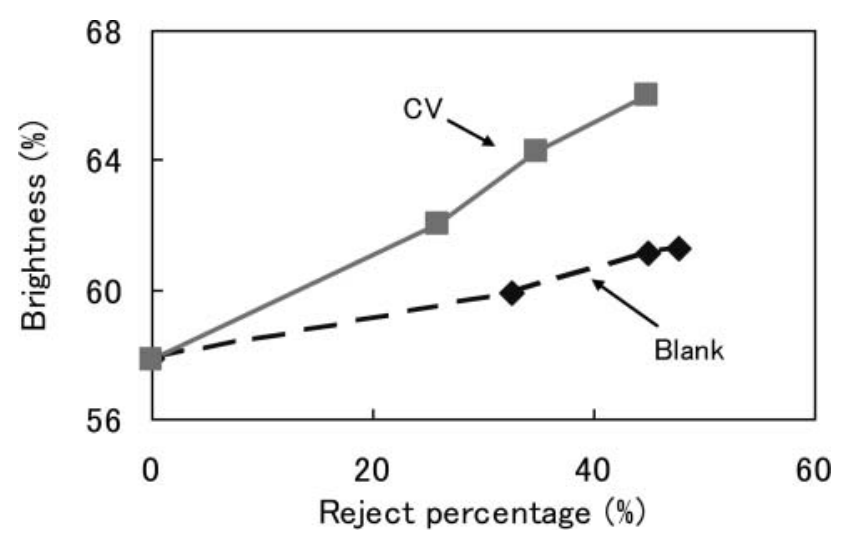

Fig. 2 The relationship between the reject percentage and the brightness of the filtrate pads from blank and $\mathrm{CV}$-jet treated samples.

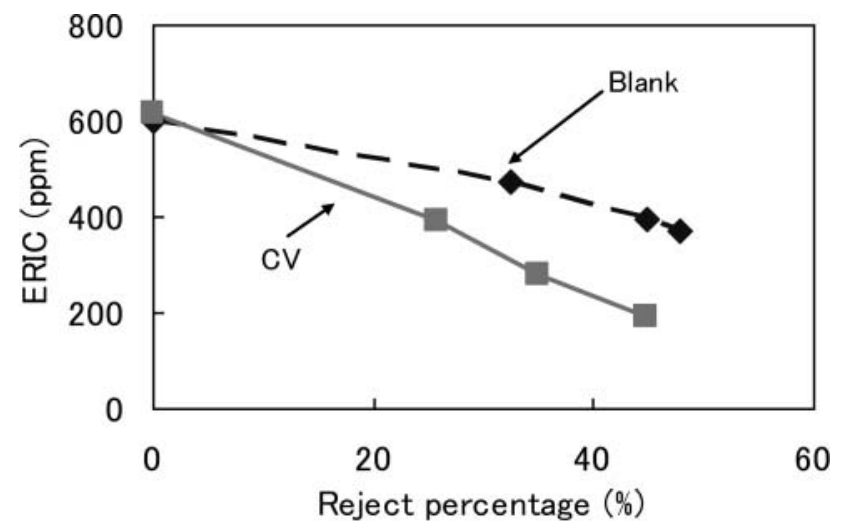

Fig. 3 The relationship between the reject percentage and the ERIC value of the filtrate pads from blank and $\mathrm{CV}$-jet treated samples.

tached on fibers. So, the $\mathrm{CV}$-jet treatment could detach ink from fiber fines.

Then Test 3 was conducted to evaluate how the CV-jet

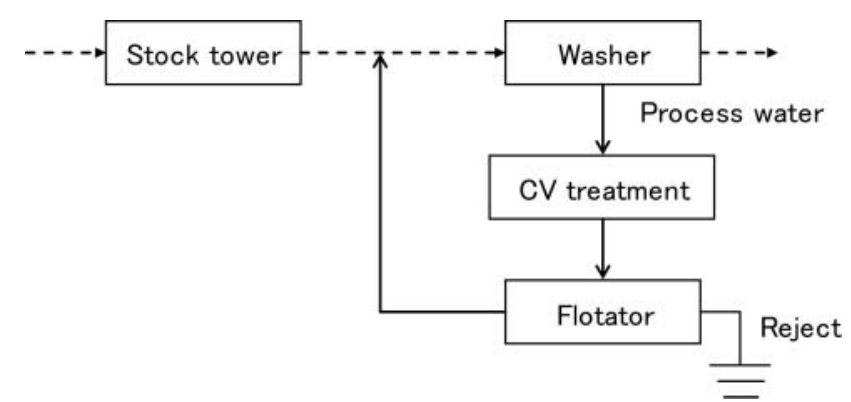

Fig. 4 The scheme around the washer and process water treatments.

treatment of mill process water would affect the efficiency of dirt removal at $\mathrm{F} / \mathrm{T}$. The result was in Table 3. Same as in Test 2, the blank and the CV-jet treated had almost the same brightness and ERIC value before $\mathrm{F} / \mathrm{T}$ treatment. After $\mathrm{F} / \mathrm{T}$, their brightness and ERIC value went up as their reject percentage increased. Fig. 2 shows their brightness changes against reject percentage and Fig. 3 is for ERIC changes as well. When compared at the same reject percentage, the $\mathrm{CV}$-jet treated had significantly higher brightness and lower ERIC value than the blank. The CV-jet treatment clearly improved ink removal at F/ T.

It was concluded that $\mathrm{CV}$-jet treatment detached ink from fiber fines and improved ink removal at following $\mathrm{F}$ / T. Figures 2 and 3 showed that the $\mathrm{CV}$-jet treatment increased brightness by 5 points and reduced the amount of ink by a half at the reject percentage of $45 \%$. Therefore, it is expected that the $\mathrm{CV}$-jet treatment will improve the quality of process water like higher brightness and lower ink content.

\subsection{Estimation of probable improvement on pulp} yield

Let us look at Figures 2 and 3 from another view point. They suggest that $\mathrm{CV}$-jet treatment will give the same quality of process water with less reject percentage than one without the treatment. When compared at the same ink amount in Fig. 3, the CV-jet treated got it at a half of reject percentage which the blank could make it. So, a flow sheet is proposed in Fig. 4, using following conditions.

*Solid discharge percentage at washer : 10\%

** Reject percentage at process water $\mathrm{F} / \mathrm{T}$

Blank : $30 \%$

CV-jet treated : $15 \%$

Washer discharges process water, which is followed by $\mathrm{F} / \mathrm{T}$. F/T will remove $30 \%$ of solid and return the rest to the washer. So, the total discharge percentage will be $3 \%$. When $\mathrm{CV}$-jet treatment is installed in the process, it will remove $15 \%$ of total solid and return $85 \%$ to washer. The total reject will be $1.5 \%$. Installing $\mathrm{CV}$-jet treatment before process water $\mathrm{F} / \mathrm{T}$ will improve pulp yield by 1.5 
points in DIP process.

\section{Conclusion}

By treating process water of DIP process by CV-jet, dirt speckles would be broken down and contaminants adhering to fine fraction like ink could be released. This effect of detachment was found not only on fiber fines but also on ash particles. When the treatment was followed by $\mathrm{F} / \mathrm{T}$, removal efficiency of ink and dirt there was improved. Therefore, the CV-jet treatment is promising as a new technology which is able to improve the quality of fine fraction of process water. It will also increase pulp yield, reduce the amount of waste discharge and refine technology of producing DIP.

\section{References}

1) Carré, B., Vernac, Y. and Beneventi, D. : Pulp Pap Can 102 (6) 33 (2001).

2) Lapierre, L., Pitre, D. and Bouchard, J. : Pulp Pap Can 104（8）36 (2003)

3) Sarja, T., et al. : Prof. Papermaking (1) 15 (2006)

4) Galland, G., et al. : Paper Recycling Challenge, Vol. 3,
Process Technology, Doshi \& Assoc. Inc., 1998, 131

5) Goto, S., Watanabe, K., Tsuji. H. and Miyanishi, T. (Nippon Paper Industries Co., Ltd.) : WO/2005/ 012632.

6) Goto, S., Tsuji. H., Watanabe, K. and Iimori, T. (Nippon Paper Industries Co., Ltd.)：WO/2006/085598.

7) Onodera, I., Watanabe, K. Goto, S., Tsuji. H. and Iimori, T. (Nippon Paper Industries Co., Ltd.) : WO/2007/ 052760.

8) Goto, S., Tsuji, H., Onodera, I., Watanabe, K. and Ono, K. : Proceedings TAPPI Engineering, Pulping \& Environmental Conference, Portland Oregon, 2008.

9) Goto, S. : Proceedings $44^{\text {th }}$ Pulp \& Paper Symposium by Society of Fiber Science and Technology, Tokyo, 2009, p 1-13

10) Soyama, H., Saito, K. and Saka M. : Trans. ASME, J. Eng. Materials Tech. 124（2）135（2002）

11) Soyama, H. Lichtarowicz, A., Momma, T. and Williams, E. J. : Trans. ASME, J. Fluids Eng. 120 (4) 712 (1998)

(Manuscript accepted 18 January, 2012) 